MARIA PASZTOR

Instytut Stosunków Międzynarodowych, Uniwersytet Warszawski

\title{
SPÓR O TRIEST W RELACJACH DYPLOMATYCZNYCH POLSKO-WŁOSKICH W LATACH 1945-1947
}

Zaproszenie Polski w trakcie londyńskiej sesji Rady Ministrów Spraw Zagranicznych wielkich mocarstw (15 IX 1945), przygotowujących traktaty pokojowe z państwami satelickimi III Rzeszy, do wypowiedzenia opinii w sprawie rozwiązań traktatowych dla Włoch, a następnie uznanie jej za sygnatariusza przyszłego traktatu pokojowego z tym krajem sprawiły, iż Warszawa stała się członkiem komisji polityczno-terytorialnej i ekonomicznej do spraw Włoch na konferencji paryskiej w okresie od 29 lipca do 15 października 1946 r. ${ }^{1}$ Rezultatów nie przyniosła akcja dyplomacji włoskiej zmierzającej do wyeliminowania Warszawy z grona państw sygnatariuszy traktatu pokojowego z Włochami, uzasadniającej swe stanowisko faktem, iż Włochy nigdy nie wypowiedziały Polsce wojny². Obawy Palazzo Chigi w tej kwestii podyktowane były obawami przed żądaniami Warszawy dotyczącymi reparacji wojennych oraz spodziewanymi komplikacjami wynikającymi z jej usytuowania w radzieckiej strefie wpływów ${ }^{3}$.

Jednak mimo argumentacji strony włoskiej, podnoszącej wobec aliantów kwestię faktu niezaistnienia de iure stanu wojny między dwoma państwami, mocarstwa uznały, zgodnie z postulatami polskimi, iż działania polskich formacji zbrojnych u boku aliantów wobec faszystowskich Włoch równoznaczne były z powstaniem stanu wojny między obydwoma państwami. O stanowisku mocarstw w tej sprawie przesądził ostatecznie

${ }^{1}$ R. Zięba, Stanowisko Polski w sprawie paryskich traktatów pokojowych 1947, Warszawa 1981, s. 51-55, 77-82.

${ }^{2}$ A. Tarchiani do premiera i ministra spraw zagranicznych, A. De Gasperiego, Waszyngton, 21 I 1946, w: I documenti diplomatici italiani (dalej: DDI), serie 10: 1943-1948, vol. 3: (10 dicembre 1945-12 luglio 1946), red. P. Pastorelli, Roma 1993, dok. 577.

${ }^{3}$ A. De Gasperi do A. Tarchianiego, Rzym, 27 I 1946, DDI, serie 10, vol. 3, dok. 613. 
udział polskich jednostek w operacjach aliantów na froncie afrykańskim i Morzu Śródziemnym ${ }^{4}$.

Decyzja mocarstw o przyszłym udziale delegacji polskiej w pracach wspomnianej komisji wpłynęła na uelastycznienie postawy władz włoskich w relacjach bilateralnych z Warszawą, przyczyniając się do zdystansowania się rządu włoskiego wobec stacjonującego we Włoszech 2 Korpusu gen. Władysława Andersa, prowadzącego nadal na tym terytorium rekrutację. Fakt ten był przyczyną wzrastającego napięcia nie tylko między rządem polskim i brytyjskim ${ }^{5}$, ale między Warszawą a Rzymem. Zaangażowanie się Polski w przygotowanie traktatu pokojowego dla Włoch w kwestiach dla tego kraju priorytetowych, tj. zobowiązań reparacyjnych, a zwłaszcza spornej kwestii granicy jugosłowiańsko-włoskiej, sprawiło, iż problemy związane ze stacjonowaniem 2 Korpusu na terenie Włoch i naciski Warszawy, dotyczące powrotu żołnierzy tej formacji do kraju, stawiały rząd włoski w wyjątkowo trudnej sytuacji nie tylko wobec władz polskich, ale i radzieckich, wobec których rząd Alcide De Gasperiego prowadził realistyczną politykę unikania zadrażnieńn ${ }^{6}$

\section{Polska wobec włosko-jugosłowiańskiego sporu o Triest}

Rzym nie ukrywał, iż liczył na poparcie rządu w Warszawie w kwestii przynależności Triestu do Włoch. Tym bardziej że jeszcze na wiosnę $1945 \mathrm{r}$. przedstawiciele Rządu Tymczasowego zapewniali włoskiego ambasadora w Moskwie o swych „sympatiach" dla Włochów oraz przyszłym wsparciu postulatów Palazzo Chigi w tej materii ${ }^{7}$. Mimo braku złudzeń względem suwerenności polskiego rządu oraz przeświadczenia, iż to od postawy Związku Radzieckiego (oraz Anglosasów), a nie Warszawy czy Pragi będzie zależał los Wenecji Julijskiej i Triestu, włoska dyplomacja nie rezygnowała z prób pozyskania życzliwości rządów tych krajów. Zwłaszcza że od postawy rządu warszawskiego zależał również los jeńców żołnierzy włoskich znajdujących

\footnotetext{
${ }^{4}$ W. Materski, Proces kształtowania się granic i sojuszy politycznych (lipiec 1945-marzec 1947), w: Historia dyplomacji polskiej, t. 6: 1944/1945-1989, red. W. Materski, W. Michowicz, Warszawa 2010, s. 269. Po 8 września 1943 r. Włochy uznane zostały przez aliantów za stronę walczącą z Niemcami i stały się sprzymierzeńcem Polski.

${ }^{5}$ W. Materski, op. cit., s. 195-198.

${ }^{6}$ A. De Gasperi do E. Realego, Rzym, 12 I 1946, DDI, serie 10, vol. 3, dok. 116; szerzej o rozmowach polsko-brytyjskich w sprawie Polskich Sił Zbrojnych i 2 Korpusu - zob. W. Materski, op. cit., s. 195-199, 230.

${ }^{7}$ P. Quaroni do A. De Gasperiego, Moskwa, 13 V 1945, DDI, serie 10, vol. 2: (12 dicembre 1944-9 dicembre 1945), red. E. Di Nolfo, Roma 1992, dok. 194.
} 
się w obozach jenieckich na terenie Polski ${ }^{8}$, a także los przedwojennych przedsiębiorstw (m.in. Fiat), towarzystw ubezpieczeniowych (Assicurazioni Generali) i kapitałów zainwestowanych w Polsce (Banca Commerciale). Włosi liczyli również na dostawy polskiego węgla, niezbędnego dla rozwoju ich przemysłu ciężkiego ${ }^{9}$. Polacy z kolei mieli na względzie szybkie uregulowanie problemu 2 Korpusu oraz uznanie przez rząd włoski Tymczasowego Rządu Jedności Narodowej ${ }^{10}$.

Chociaż ambasador włoski w Moskwie Pietro Quaroni zdawał sobie sprawę, że możliwości Polaków i (Czechów) „wpływania” na ZSRR w sprawie spornych obszarów „są minimalne”, to jednak „w aktualnej sytuacji”twierdził: „nie należy zaniedbywać żadnej, nawet najmniejszej możliwości". Ambasadorowi wydawało się to poparcie tym bardziej prawdopodobne, iż jak pisał w swym raporcie z tej placówki, „,Polacy i Czesi mogą mieć w tym pewien interes, aby Triest, w którym zbiegają się ważne dla nich rynki zbytu, nie znalazł się całkowicie w rękach rosyjskich" (tj. zwolenników Josipa Broz-Tity) ${ }^{11}$.

Temu właśnie celowi służyć miały wspomniane wyżej rozmowy z przedstawicielami Rządu Tymczasowego w Moskwie prowadzone przez P. Quaroniego, w tym spotkania z ambasadorem Zygmuntem Modzelewskim oraz ministrem spraw zagranicznych tego rządu Wincentym Rzymowskim. Włoski dyplomata sondował nawet Rzymowskiego w kwestii ewentualnej interwencji Polski w sprawie Triestu u marszałka Tity, na rzecz Włochów. Uzyskał zapewnienie polskiego ministra, iż podziela on włoski punkt widzenia i „jeśli będzie mógł być użyteczny w jakikolwiek sposób, to uczyni to chętnie z przyjaźni do Włoch". Rzymowski nie omieszkał jednak zapytać swego rozmówcę o stosunek ZSRR do tego problemu $^{12}$. Tymczasem stanowisko Kremla na wiosnę 1945 r. w obliczu

828 kwietnia 1945 r. został podpisany polsko-włoski układ o wzajemnej ochronie obywateli i jeńców wojennych. Zob. K. Strzałka, Między przyjaźnią a wrogością. Z dziejów stosunków polsko-włoskich (1939-1945), Kraków 2001, s. 424-430.

${ }^{9} \mathrm{~W}$ drugiej połowie czerwca $1945 \mathrm{r}$. ambasada Rządu Tymczasowego w ZSRR zaproponowała Włochom nawiązanie stosunków handlowych, oferując dostawy węgla w zamian za produkty włoskiego przemysłu lekkiego, zob. K. Strzałka, op. cit., s. 442. O obozach jenieckich na terenie Polski zob. W. Materski, Dyplomacja Polski „lubelskiej”, lipiec 1944-marzec 1947, Warszawa 2007, s. 278.

${ }^{10}$ O okolicznościach uznania TRJN przez włoską Radę Ministrów (6 VII 1945) zob. K. Strzałka, op. cit., s. 454-456.

11 P. Quaroni do A. De Gasperiego, Moskwa, 13 V 1945, DDI, serie 10, vol. 2, dok. 194.

12 „Rzymowski mi ha alora detto [- - ] che poteva essere sicuro che se avesse potuto in qualche modo essere utile all'Italia, sarebbe stato ben lieto di farlo", P. Quaroni do A. De Gasperiego, Moskwa, 30 VI 1945, DDI, serie 10, vol. 2, dok. 229. P. Quaroni odpisał, że chociaż rząd ZSRR nie opowiedział się jeszcze po żadnej ze stron konfliktu, zachowując postawę neutralną („pesce in barile”), to jednak wydaje się, że w gruncie 
niejasnej i mogącej doprowadzić do erupcji konfliktu zbrojnego między mocarstwami sytuacji, jaka zaistniała na tym spornym obszarze, było nie do końca jasne nie tylko dla Rzymu, ale i dla Warszawy. Ta ostatnia zapewniała jednak Włochów, że Moskwa „nie zamierza się wtrącać w sprawę Triestu" oraz że rada, której Kreml udzielił Ticie w tej materii, sprowadzała się do konieczności unikania otwartego konfliktu i podjęcia bezpośrednich negocjacji między zainteresowanymi stronami ${ }^{13}$.

Stalin bowiem, wobec utrzymującego się napięcia brytyjsko-jugosłowiańskiego związanego z interwencją wojsk anglosaskich na obszarze Wenecji Julijskiej i Triestu na przełomie kwietnia i maja 1945 r., zajętych uprzednio przez 4 Armię jugosłowiańską, zachowywał się nader powściągliwie $^{14}$.Jego postawa sprowadzała się do przyjęcia filozofii określonej przez włoskiego historyka Silvia Ponsa jako wait-and-see $e^{15}$. Linia polityczna radzieckiego kierownictwa, zaskoczonego determinacją Winstona Churchilla w sprawie przynależności Triestu, stanowiącego kluczowy punkt strategiczny otwierający drogę na Bałkany, jednak tylko pozornie wykazywała chwiejność, jak zdawałoby się na to wskazywać zachowanie Stalina.Poparł on na wstępie podjęcie przez jugosłowiańskie siły zbrojne kwietniowej ofensywy, mającej na celu zajęcie Triestu z wyprzedzeniem sił brytyjskich. Jak wynikało z informacji ambasadora P. Quaroniego, inicjatywa Tity podjęta została za wiedzą i zgodą Moskwy, która udzieliła armii jugosłowiańskiej pomocy materiałowej ${ }^{16}$. W końcu maja $1945 \mathrm{r}$. Stalin poinformował nawet (razem z przewodniczącym Kominternu Georgim Dimitrowem (Georgi Dimitrov), przywódcę Włoskiej Partii Komunistycznej, Palmira Togliattiego o konieczności cesji Triestu na rzecz Jugosławii, a następnie po kilku dniach, zapewne w wyniku determinacji dowództwa sił angloamerykań-

rzeczy sprzyja żądaniom Jugosławii. Zob. też: P. Quaroni do A. De Gasperiego, Moskwa, 27 V 1945, DDI, serie 10, vol. 2, dok. 221.

13 P. Quaroni do A. De Gasperiego, Moskwa, 27 V 1945, DDI, serie 10, vol. 2, dok. 221.

${ }^{14}$ O przebiegu konfliktu o Triest zob. K. Szczepanik, J. Wilamowski, Międzynarodowy spór o Triest i jego rozstrzygnięcie, „Sprawy Międzynarodowe” 1982, 12 (355); T. Wituch, Spór o Triest - wczesny epizod „zimnej wojny”, DN 29, 1997, 2 (19); J.-B. Duroselle, Le conflit de Trieste 1943-1954, Bruxelles 1966, s. 192-201. O wcześniejszym stanowisku ZSRR wobec granicy jugosłowiańsko-włoskiej oraz poparciu dla Tity ze strony Moskwy zob. H. Bartoszewicz, Polityka Związu Sowieckiego wobec państw Europy Środkowo-Wschodniej w latach 1944-1948, Warszawa 1999, s. 145-146, 178.

${ }^{15}$ S. Pons, Stalin, Togliatti, and the Origins of the cold War in Europe, ,Journal of Cold War Studies" 2001, 2001, 2 (5), s. 12.

${ }^{16}$ P. Quaroni do A. De Gasperiego, Moskwa, 27 V 1945, DDI, serie 10, vol. 2, dok. 221; L. Gibianskii, The Soviet Bloc and the Initial Stage of the Cold War: Archival Documents on Stalin's Meetings with Communist Leaders of Yugoslavia and Bulgaria, 1946-1948, „Cold War International History Project Bulletin" 1998, 10, s. 115, 〈http://www.wilsoncenter. org/publication/bulletin-no-10-march-1998 (dostęp: 1 VII 2014). 
skich, które wkraczając do Triestu, domagały się opuszczenia przez Jugosłowian obszarów na zachód od dawnej granicy jugosłowiańsko-włoskiej, zmienił decyzję. Jego naciski na Titę zmierzały w kierunku zmiany bezkompromisowej postawy jugosłowiańskiego przywódcy. Owa elastyczność czy też „zmienność” polityki Stalina wynikała z jego pragmatyzmu, zasadzającego się na konieczności unikania konfliktu zbrojnego z mocarstwami anglosaskimi, w którym ZSRR nie mógł liczyć na zwycięstwo. Utrzymanie i umocnienie powojennego stanu posiadania, a nie jego rozszerzanie za wszelką cenę, stanowiło bowiem najważniejszy priorytet powojennej polityki radzieckiego przywódcy. Jak trafnie zauważyli niektórzy historycy, efektem takiej polityki Stalina miało być przede wszystkim doprowadzenie do „utrzymania Europy podzielonej i uległej”, co stanowiło cel nadrzędny wobec nierealnych perspektyw jej skomunizowania ${ }^{17}$. Zapewne presji Stalina, obawiającego się wspomnianej konfrontacji militarnej, która mogła zakończyć się ostateczną porażką Tity i doprowadzić przy okazji do utraty wpływów przez ZSRR w całym regionie, należy przypisać zgodę jugosłowiańskiego przywódcy na podpisanie wstępnego porozumienia (6 V 1945) z Anglosasami ${ }^{18}$. Na jego podstawie brytyjski komendant miasta uznał miejscową administrację jugosłowiańską, a jednostki alianckie zachowały prawo do korzystania z portu i połączeń komunikacyjnych ${ }^{19}$.

Powyższe rozwiązanie, podobnie jak podpisane (9 i 20 VI 1945) porozumienie dzielące konfliktogenny obszar na dwie strefy, nie kończyło sporu, pozostawiając wszelkie kwestie terytorialne do rozstrzygnięcia na przyszłej konferencji pokojowej ${ }^{20}$. Porozumienie miało obowiązywać do momentu podpisania z Włochami traktatu pokojowego.

${ }^{17}$ V. Mastny, The Cold War and Soviet Insecurity: The Stalin Years, Oxford 1996, s. 21; S. Pons, op. cit., s. 5.

${ }^{18}$ V.Zubok,Nieudane imperium. Zwiazek Radziecki okresu zimnej wojny,od Stalina do Gorbaczowa, Kraków 2010 (oryg. ang. 2007), s.24; V. O.Pechatnov, , The Allies are Pressing on you to Breakyour Will...". Foreign Policy Correspondence between Stalin and Molotov and Other Politburo Members, September 1945-December 1946, Washington, D. C. 1999, Cold War International History Project Working Paper, 26, s. 1-2, 〈http://www.wilsoncenter.org/publication/the -allies-are-pressing-you-to-break-your-will-foreign-policy-correspondence-between $\rangle$ (dostęp: 1 VII 2014).

${ }^{19}$ K. Szczepanik, J. Wilamowski, op. cit., s. 108; Z. Rutyna, Jugosławia na arenie międzynarodowej 1943-1948, Warszawa 1981, s. 170-178.

${ }^{20}$ Obszar sporny został podzielony na dwie strefy (tzw. strefa A z Triestem i Pulą znalazła się pod zarządem armii brytyjskiej i amerykańskiej, strefa B (Isola, Capo d'Istria, Pirano, Umago i Buje) znalazła się pod kontrolą Jugosławii. Siły jugosłowiańskie zobowiązane zostały do opuszczenia strefy A, co nastąpiło 12 czerwca $1945 \mathrm{r}$. 20 czerwca 1945 r. przyjęto tymczasową linię demarkacyjną, rozdzielającą wojska w obu strefach, zwaną linią Morgana, która zostawiła Triest i Pulę w rękach aliantów, a cały półwysep Istria - po stronie jugosłowiańskiej. Zob. Z. Rutyna, op. cit., s. 170-178. 
W tej sytuacji logiczna wydawała się reakcja radzieckich czynników oficjalnych na przemówienie marszałka Tity (27 V 1945), w którym stwierdził on, że „Jugosławia nie zgodzi się, aby jej żywotne interesy stały się kartą przetargową". Z zamieszczonego tego dnia w „Prawdzie” artykułu J. Wiktorowa pt. O kwestii triesteńskiej wynikało, iż akceptacja sytuacji w Trieście dotyczy jedynie okresu przejściowego, a los tego miasta zostanie rozstrzygnięty na mocy przyszłego traktatu pokojowego z Włochami ${ }^{21}$. Potwierdzało to zdystansowanie się Kremla od zaangażowania się w militarne poparcie Tity oraz wskazywało, że postawa ZSRR zależeć będzie od dalszego rozwoju wydarzeń i rozstrzygnięć w sprawie podziału wpływów między mocarstwami ${ }^{22}$.

$\mathrm{Z}$ analizy polityki radzieckiego kierownictwa i enuncjacji polskiego ambasadora, który przekonywał swego rozmówcę, iż został upoważniony przez Kreml do prowadzenia z nim rozmów w sprawie Triestu, włoski ambasador w ZSRR wyciągnął, jak się wydaje częściowo przynajmniej uprawniony wniosek, że „w tej fazie konfliktu ZSRR nie jest skłonny do końca popierać działań Jugosławii”. Oceniał on, iż w sprawie włoskich granic wschodnich „Rosja ustąpi tylko wobec zdecydowanego sprzeciwu Anglosasów"23. Zapewnienia polskich dyplomatów i czynników oficjalnych o poparciu włoskich żądań terytorialnych przez polskie władze wydawały się Warszawie bezpieczne, gdyż jak na wyrost oceniano, były one zbieżne z kierunkiem linii politycznej Moskwy. Tym bardziej że Tymczasowy Rząd Jedności Narodowej zabiegał w Rzymie o uznanie, które nastąpiło 6 lipca 1945 r. (wkrótce po tym, jak uczyniła to Francja, Wielka Brytania i Stany Zjednoczone).

Tymczasem nie mając pewności względem determinacji zachodnich mocarstw w tym konflikcie, rząd włoski starał się lawirować między trzema mocarstwami, wykorzystując w miarę swych niewielkich możliwości sprzeczności między nimi, oraz pozyskać ich życzliwość. Owa „podwójna gra” włoskiej dyplomacji miała w efekcie doprowadzić do uzyskania ko-

${ }^{21}$ T. Wituch, op. cit., s. 84. Ambasador P. Quaroni pisał nawet o „ostrożnej rezerwie” („la prudente riserva”) prasy sowieckiej „wobec wszystkich kwestii związanych z Triestem". Zob. P. Quaroni do A. De Gasperiego, Moskwa, 27 V 1945, DDI, serie 10, vol. 2, dok. 221.

${ }^{22}$ Por. T. Wituch, op. cit., s. 82 . Według Vladislava Zuboka oświadczenie Tity stanowiło w oczach Stalina „poważny afront”. Pisze on, że „zapewne w tym momencie Stalin zaczął patrzeć na Titę z podejrzliwością”. Zob. V.Zubok, op. cit., s. 24.

${ }^{23}$ „Secondo me [- - ] nella questione dei nostri confini la Russia cederà solo ad una recisa opposizione anglo-ameriacana”, P. Quaroni do A. De Gasperiego, Moskwa, 27 V 1945, DDI, serie 10, vol. 2, dok. 221. 
rzystniejszych dla Włoch warunków przyszłego traktatu pokojowego i zminimalizowania strat terytorialnych ${ }^{24}$.

Rezygnacja Kremla z militarnego wsparcia Belgradu w sprawie Triestu i Wenecji Julijskiej (maj-czerwiec 1945) nie oznaczała bynajmniej wycofania się z popierania przez dyplomację radziecką postulatów Belgradu. Podczas konferencji poczdamskiej Stalin przeciwstawił się podjętym przez W. Churchilla próbom modyfikacji układu z 9 czerwca $1945 \mathrm{r}^{25} \mathrm{Bez}-$ pośrednio po jej zakończeniu dyplomaci radzieccy ostrzegali Jugosłowian, że Anglosasi posłużą się Włochami i poprą ich żądania terytorialne na szkodę Jugosławii. Kierownictwo radzieckiego Ministerstwa Spraw Zagranicznych wyraźnie dało przy tym do zrozumienia jugosłowiańskiemu ambasadorowi w Moskwie, iż na przyszłe rozstrzygnięcia terytorialne decydujący wpływ będzie miała postawa delegacji radzieckiej ${ }^{26}$.

O poparciu ZSRR dla Jugosławii świadczy konsekwentna postawa delegacji na londyńskiej sesji RMSZ mocarstw we wrześniu 1945 r., gdzie po raz pierwszy omawiano zagadnienie rewizji granicy jugosłowiańsko-włoskiej. Radziecki minister spraw zagranicznych Wiaczesław Mołotow (Vâčeslav Mihajlovič Molotov) poparł postulaty zawarte w memorandum rządu jugosłowiańskiego (z 13 IX 1945). Zawierało ono żądania całkowitego zwierzchnictwa Jugosławii nad Istrią, Triestem i zachodnią częścią Wenecji Julijskiej wraz z Gorycją. Nie znalazła przychylności Włochów propozycja Belgradu przyznania temu terytorium statusu „odrębnego państwa federalnego" w ramach Ludowej Federacji Republiki Jugosławii oraz nadania mu autonomii. Niniejsze stanowisko spotkało się z dezaprobatą nie tylko delegacji włoskiej, ale i mocarstw zachodnich, które skłaniały się do koncepcji przyznania Włochom Triestu oraz umiędzynarodowienia jego okręgu ${ }^{27}$. W rezultacie braku porozumienia problem ten został ponownie odłożony do konferencji pokojowej ${ }^{28}$.

${ }^{24}$ Wydawało się to tym bardziej uzasadnione, że jeszcze w roku 1944 oraz na początku 1945 Brytyjczycy zdawali się wspierać ambitne plany Tity. Zob. E. Aga-Rossi, V. Zaslavsky, Togliatti e Stalin. Il PCI e la politica estera staliniana negli archivi di Mosca, Bologna 1997, s. 139; R. Morozzo Della Rocca, La politica estera italiana e l'Unione Sovietica 1944-1948, Roma 1985, s.147-153.

${ }^{25}$ Zob. Z. Rutyna, op. cit., s. 185-187.

${ }^{26}$ V. Popović do Tity (rozmowa amb. Jugosławii w Moskwie z W. Mołotowem i A. Wyszynskim), Moskwa, 5 VIII 1945, cyt za: E. Aga-Rossi, V. Zaslavsky, op. cit., s. 153.

${ }^{27}$ R. Zięba, op. cit., s. 84. Por. L. Gibianskii, op. cit., s. 125.

${ }^{28}$ Problemu nie udało się załatwić na drodze ustaleń Czteromocarstwowej Komisji Granicznej ani na drugiej sesji RMSZ w Paryżu w lecie 1946 r., gdzie Mołotow znów zażądał przyłączenia do Jugosławii Triestu i całej Wenecji Julijskiej z Gorycją. Propozycje zachodnie przewidywały przekazanie Włochom zachodniej części Wenecji Julijskiej (w tym Triestu, Gorycji oraz części płw. Istria). 3 lipca zadecydowano o umiędzynaro- 
Tymczasem Polska, która została zaproszona na konferencję londyńską do przedstawienia opinii w sprawie traktatu pokojowego dla Włoch, znalazła się w świetle wspomnianych wyżej deklaracji w wyjątkowo niezręcznej sytuacji. W Warszawie zdawano sobie sprawę, iż ze względu na zdecydowaną postawę Anglosasów sprawa Triestu została już przesądzona na korzyść Włochów. Wyraźna zmiana frontu wobec Rzymu (zakładając przyjęcie w oświadczeniu stanowiska zgodnego z linią Kremla) zmuszała władze polskie do porzucenia życzliwej Włochom postawy i musiała doprowadzić do zadrażnień z rządem włoskim, z czego władze w Warszawie znakomicie zdawały sobie sprawę. Kierownictwo polskiego MSZ starało się wyraźnie przeciągać sprawę, próbując bez powodzenia uniknąć wejścia na teren sporu jugosłowiańsko-włoskiego czy też radziecko-angielskiego. Naczelnik wydziału zachodniego, Tadeusz Chromecki, zalecając swemu kierownictwu zajęcie stanowiska neutralnego w sprawie przynależności Triestu, pisał w swej notatce do wiceministra Z. Modzelewskiego, że oświadczenie opowiadające się za przynależnością Triestu do Jugosławii, złożone w momencie przybycia do Polski ambasadora Królestwa Włoch (22 IX 1945), komunisty Eugenia Reale, byłoby „dość szkodliwe” i „popsułoby z miejsca nasze stosunki z ambasadorem" ${ }^{29}$. Tym bardziej że wysłanie do Warszawy tego należącego do kierownictwa WłPK dyplomaty miało pomóc w przekonaniu Palazzo Chigi w pozyskaniu życzliwości polskiej delegacji na konferencję w Paryżu ${ }^{30}$. Nie oznaczało to bynajmniej pełnego zaufania kierownictwa włoskiego MSZ do osoby i sądów E. Realego, którego poglądy polityczne odbiegały od tendencji oraz opcji politycznych większości zatrudnionych tam dyplomatów ${ }^{31}$.

W Warszawie obawiano się ponadto, że zajęcie przez Polskę stanowiska popierającego w sposób jednoznaczny postulaty Belgradu może wywołać „antywarszawską reakcję" nad Tybrem, wzmocnić i tak bardzo przychylny stosunek do stacjonującego we Włoszech 2 Korpusu ${ }^{32}$ oraz urzędów rządu londyńskiego w tym kraju. Wszystko to oznaczało utrud-

dowieniu okręgu Triestu i podziale Wenecji Julijskiej według projektu francuskiego. Włochy i Francja odrzuciły w dniu 17 lipca ten projekt. Zob. R. Zięba, op. cit., s. 87.

${ }^{29}$ Archiwum Ministerstwa Spraw Zagranicznych (dalej: AMSZ), z. 6, t. 1266, w. 83, notatka T.Chromeckiego dla min. Z. Modzelewskiego, poufne, Warszawa, 24 IX 1945, b.pag.

${ }^{30}$ W. Materski, Dyplomacja Polski ,lubelskiej”, s. 278.

${ }^{31}$ Kwestię komplikuje rozbieżność między osądami Realego zawartymi w jego raportach z Polski wydanych we włoskich dokumentach dyplomatycznych a jego opiniami wyrażonymi w listach do Togliattiego. Zob. P. Cacace, Venti anni di politica estera italiana (1943-1963), Roma 1986, s. 17. Por. A. Carioti, Eugenio Reale l'uomo che sfidò Togliatti, Firenze 1998, s. 104-109.

${ }^{32}$ R. Prunas do A. De Gasperiego, Rzym, 6 VII 1945, DDI, serie 10, vol. 2, dok. 313. 
nienie misji ambasadora Stanisława Kota, który miał na początku października 1945 r. przybyć do Rzymu ${ }^{33}$. Zapewne naciski Moskwy zmusiły rząd warszawski do sprecyzowania stanowiska w dokumencie znanym jako Oświadczenie Rządu Polskiego w kwestii Traktatu Pokojowego z Włochami (28 IX 1945), który został 30 września przekazany obradującej w Londynie RMSZ mocarstw. Dokument podpisany przez premiera Edwarda Osóbkę-Morawskiego i ministra spraw zagranicznych W. Rzymowskiego, powołując się na wkład narodów Jugosławii w zwycięstwo nad faszyzmem, zawierał propozycję rozstrzygnięć terytorialnych jednoznacznie korzystnych dla Belgradu, przekreślając wcześniejsze deklaracje przedstawicieli TRJN. Opowiadał się bowiem za włączeniem w skład Federacji Jugosławii Istrii, Fiume (Rijeki) i Zadaru, miasta Triestu (przy utrzymaniu jego samorządu w ramach państwa jugosłowiańskiego). Zakładał ponadto przyznanie statusu międzynarodowego portowi w Trieście, który miał zostać udostępniony wszystkim zainteresowanym państwom ze „szczególnym uwzględnieniem praw i potrzeb Jugosławii”. Polska zastrzegła sobie udział w ewentualnych międzynarodowych instancjach sprawujących nadzór nad portem w Trieście względnie nim administrujących ${ }^{34}$. Upowszechnienie stanowiska Polski zajętego w memorandum (5 października) i opublikowanie (9 października) w gazecie „Rzeczpospolita" stanowiska Polski na konferencji londyńskiej wywołało zgodnie z przewidywaniem Warszawy negatywną reakcję ambasadora Reale, który na prośbę swej centrali zażądał od ministra Z. Modzelewskiego wyjaśnień. Ten próbował zbagatelizować publikację dziennika, wyrażając przekonanie, że „Triest, włoskie miasto, pozostanie przy Włoszech mimo manewrów in extremis Tity, który w chwili obecnej był skłonny przyznać Triestowi szeroką autonomię w ramach Federacji Jugosławii i wyrażał zgodę na umiędzynarodowienie portu". Polski minister nie krył przy tym swych oczekiwań związanych z kłopotami wewnętrznymi rządu Tity i nadziei na jego rychły upadek ${ }^{35}$. Analogiczne stanowisko Z. Modzelewski zajął w rozmowie z E. Realem na początku stycznia 1946 r., podkreślając, że mimo nacisków ambasadora Jugosławii, Božidara Ljumovicia, domagającego się poparcia stanowiska jego kraju w sprawie przynależności terytorialnej Wenecji Julijskiej, a zwłaszcza Triestu, Polacy zachowali dystans. Odpowiedź udzielona jugosłowiańskiemu dyplomacie sprowadzać się miała do stwierdzenia, iż „przynależność spornego terytorium winna być

${ }^{33}$ Szerzej na temat misji S. Kota w Rzymie w okresie od września 1945 r. do października 1947 r. zob. T.P. Rutkowski, Stanisław Kot 1885-1975. Biografia polityczna, Warszawa 2000, s. 368-394.

${ }^{34}$ R. Zięba, op. cit., s. 85-87; W. Materski, Dyplomacja Polski „lubelskiej”, s. 280.

${ }^{35}$ E. Reale do A. De Gasperiego, Warszawa, 12 X 1945, DDI, serie 10, vol. 2, dok. 620. 
rozstrzygnięta w oparciu o kryterium narodowościowe większości mieszkańców". Strona polska miała potwierdzić w rozmowie z B. Ljumoviciem postulat umiędzynarodowienia portu i konieczność umiejscowienia się w jego radzie administracyjnej, ze względu na - jak to określono - polskie interesy nawigacyjne ${ }^{36}$. Stanowisko niniejsze Warszawa rzeczywiście podtrzymywała w rozmowach z jugosłowiańskimi dyplomatami, odmawiając w zimie 1946 r. bardziej zdecydowanego zaangażowania się w sprawę granicy jugosłowiańsko-włoskiej po stronie Belgradu. Zaambarasowanie i sprzeciw urzędników polskiego MSZ budziły przytaczane przez jugosłowiańskich rozmówców argumenty, iż "Jugosławia uważa nasze granice za swe własne i jak własnych bronić ich będzie, i że tego samego oczekuje od nas w odniesieniu do Krainy, Istrii i Triestu”. Odpierali oni co prawda zarzuty Jugosłowian, iż „wzgląd na Włochów dyktuje nam powstrzymanie prasy od wypowiedzenia się w sprawie Triestu", ale opierając się naciskom Jugosłowian, ograniczali się do ogólnych enuncjacji, że „nasze stosunki z Włochami nie mają i nie mogą mieć wpływu na naszą wzajemną przyjaźn" ${ }^{37}$.

Stanowisko Warszawy prezentowane stronie włoskiej i jugosłowiańskiej odbiegało więc wyraźnie od poglądu zawartego w memorandum z 29 września 1945 r., stanowiąc desperacką próbę rewizji wcześniejszej postawy i zachowania wąskiego marginesu swobody działania. Warszawa bowiem, widząc brak szans w ówczesnym układzie sił na przychylne dla Belgradu załatwienie sprawy Triestu oraz własne interesy we Włoszech, niechętnie angażowała się po stronie Tity, unikając w swych oficjalnych enuncjacjach stawiania kwestii przynależności państwowej tego miasta ${ }^{38}$. Wśród polskich dyplomatów przeważała bowiem opinia, że nie warto się angażować w przegranej sprawie, zrażając sobie drugą stronę bez realne-

${ }^{36}$ Archivio Storico del Ministero degli Affari Esteri (Archiwum Historyczne Ministerstwa Spraw Zagranicznych w Rzymie) (dalej: ASMAE), Polonia 1946-1950, 3 busta, nr 36, E. Reale do A. De Gasperiego, Warszawa, 7 I 1946, b.pag. Por. E. Reale do Królewskiego MSZ w Rzymie, 6 I 1946, w: E. Reale, Raporty. Polska 1945-1946, Warszawa 1991 (oryg. wł. niepubl., 1. wyd. pol. 1968), s. 109.

${ }^{37} \mathrm{~W}$ rozmowie z radcą amb. Jugosławii, Labudem Kusovacem, Wiesław Sobierajski stwierdził: „ze sposobu przedstawienia sprawy odniosłem wrażenie, iż liczy się z tą ewentualnością, że Związek Radziecki nie poprze do końca ich rewindykacji terytorialnych w całej rozciągłości, że może pójść na pewne ustępstwa taktyczne w tej kwestii na rzecz aliantów zachodnich", AMSZ, z. 6, t. 1246, w. 17, notatka W. Sobierajskiego, Warszawa, 31 I 1946, b.pag.

${ }^{38} \mathrm{Z}$ projektu rezolucji Komitetu Słowiańskiego T. Chromecki wykreślił sformułowania, które dotyczyły przyłączenia Wenecji Julijskiej i Triestu do Jugosławii. Sobierajski pisał, że Chromecki żąda przyłączenia Triestu, a Polacy przewidują tylko jego umiędzynarodowienie. AMSZ, z. 6, t. 1266, w. 83, W. Sobierajski do min. W. Rzymowskiego, Warszawa, 31 I 1946. 
go poparcia pierwszej oraz bez uzyskania wyraźnych korzyści ${ }^{39}$. Belgrad bowiem unikał angażowania się w spór polsko-czechosłowacki o śląsk Cieszyński ${ }^{40}$. Ponadto w kierownictwie MSZ zdawało się utrwalać przekonanie, że na przyszłej konferencji ZSRR nie poprze w pełni Jugosławii, lecz ulegnie naciskom angielsko-amerykańskim w sprawie Triestu, by uzyskać koncesje w Bułgarii, Rumunii i w Polsce ${ }^{41}$. Takie też przekonanie żywiły na początku roku 1946 również mocarstwa zachodnie ${ }^{42}$.

Dodatkowo Warszawę zastanawiała postawa WłPK, która jak donosił ambasador RP w Jugosławii, Jan Karol Wende, na początku 1946 r. „oświadczyła ustami swego sekretarza generalnego (P. Togliattiego), w przeciwieństwie do stanowiska zajętego pół roku wstecz, że Triest jest włoski i że powinien należeć do Włoch" 43 , co w kontekście zbliżających się wyborów parlamentarnych w tym kraju (2 VI 1946) nabierało szczególnego znaczenia i skłaniało polskie władze do zachowania rezerwy wobec inicjatyw zgłaszanych przez Titę.

Palazzo Chigi, mając na uwadze, iż władze warszawskie wejdą w skład delegacji, która będzie przygotowywała traktaty pokojowe z byłymi państwami satelickimi w Paryżu, starał się również unikać zadrażnień, podejmując kroki w Watykanie zmierzające do ograniczenia do „niezbędnych obowiązków" działalności ambasadora rządu londyńskiego przy Stolicy Apostolskiej, Kazimierza Papée ${ }^{44}$. Podobne działania rząd włoski usiłował przedsięwziąć w Waszyngtonie i Londynie wobec stacjonującego we Włoszech 2 Korpusu, zarzucając gen. Andersowi, zgodnie zresztą z sugestiami Warszawy, torpedowanie działań zmierzających do demobilizacji polskich

${ }^{39}$ AMSZ, z. 6, t. 1246, w. 17,J.K. Wende do W. Rzymowskiego, Belgrad, 18 II 1946, b.pag.

${ }^{40}$ Kusovac wskazywał swemu rozmówcy na politykę Jugosławii „niemieszania się w konflikt bratnich krajów", AMSZ, z. 6, t. 1246, w. 17, notatka W. Sobierajskiego z rozmowy z radcą amb. Jugosławii, Kusowaczem, Warszawa, 31 I 1946, b.pag.

${ }^{41}$ Zob. E. Reale do Królewskiego MSZ w Rzymie, 6 I 1946, w: E. Reale, op. cit., s. 109.

${ }^{42}$ D. De Castro, La Questione di Trieste. L'azione politica e diplomatica italiana dal 1943 al 1954, vol. 1, Trieste 1981, s. 422.12 kwietnia amb. Włoch w USA Alberto Tarchiani donosił Palazzo Chigi, że Departament Stanu podzielał pogląd francuskiego szefa MSZ Maurice'a Couve'a de Murville'a, że ZSRR „nie będzie się bił do końca o przyznanie Triestu Jugosławii". Tarchiani wskazywał przy tym na zdeterminowaną postawę USA w sprawie Triestu. Jeszcze w lutym 1946 r. amb. P. Quaroni informował swoich zwierzchników o niesprecyzowanym stanowisku ZSRR w sprawie Wenecji Julijskiej. Zob. P. Quaroni do A. De Gasperiego, Moskwa, 9 II 1946, DDI, serie 10, vol. 3, dok. 175.

${ }^{43}$ AMSZ, z. 6, t. 1246, w. 17, J. K. Wende do W. Rzymowskiego, Belgrad, 18 II 1946, b.pag. O ewolucji postawy włoskich komunistów w sprawie Triestu zob. S. Pons, op. cit., s. 11-13; E. Aga-Rossi, V. Zaslavsky, op. cit., s. 139-144.

${ }^{44}$ A. De Gasperi do E. Realego, Rzym, 10 II 1946, DDI, serie 10, vol. 3, dok. 176; A. De Gasperi do amb. Włoch przy stolicy Apostolskiej, P. Diana, Rzym, 10 II 1946, ibidem, dok. 178, Rzym interweniował u Stolicy Apostolskiej w kwestii uniemożliwienia amb. K. Papéemu powołania Stowarzyszenia Polaków Dysydentów. 
sił zbrojnych na terenie Włoch oraz brak lojalności wobec ich brytyjskich zwierzchników w tej sprawie. Władze polskie usiłowały (nie bez pewnych sukcesów) wpłynąć na rząd włoski w kierunku odsyłania do Polski zdemobilizowanych żołnierzy wspomnianych jednostek ${ }^{45}$.

Nic więc dziwnego, że propozycja zawarcia układu o przyjaźni, współpracy i wzajemnej pomocy zawarta w nocie rządu jugosłowiańskiego, przekazana ministrowi W. Rzymowskiemu 15 lutego 1946 r., musiała być Warszawie szczególnie nie na rękę. Podobnie zresztą jak ponawiane przez Titę, a odkładane przez stronę polską oferty złożenia oficjalnej wizyty w Polsce, której pomysł, jak przynajmniej twierdził Tito, został uzgodniony z Moskwą ${ }^{46}$.

Dodatkowo pewne zadrażnienia w stosunkach polsko-jugosłowiańskich wywoływała sprawa stacjonowania w Trieście i w angloamerykańskiej strefie okupacyjnej (A) w Wenecji Julijskiej 2 Korpusu. W połowie lutego 1946 r. rząd Federacyjnej Ludowej Republiki Jugosławii skierował do Sekretariatu ONZ memorandum, protestując przeciwko przemieszczaniu oddziałów tej armii w kierunku tzw. zony B, zajętej przez Jugosławię ${ }^{47}$. Tego rodzaju posunięcie miało stać się według Belgradu rodzajem nacisku wobec Czteromocarstwowej Komisji Granicznej (będącej organem RMSZ), której zadaniem było przygotowanie na konferencję w Paryżu stanowiska w sprawie spornego obszaru. Jugosłowianie, którzy w swej strefie B zgromadzili znaczne oddziały wojskowe, oskarżali aliantów zachodnich o przygotowania do opanowania terenu zajętego przez Jugosławię ${ }^{48}$. Wskazując na kontakty oficerów polskiej armii z „ustaszami i innymi grupami jugosłowiańskich faszystów i zdrajców", domagali się postawienia tej kwestii na forum Rady Bezpieczeństwa ONZ, apelując do przedstawiciela ZSRR o podniesienie sprawy obecności w tej strefie wojsk polskich. Propaganda jugosłowiańska prowadziła zakrojoną na szeroką skalę akcję antypolską, donosząc o prowokowaniu przez Polaków starć granicznych z wojskiem

${ }^{45}$ R. Prunas do C. Soardiego, Rzym, 17 III 1946, DDI, serie 10, vol. 3, dok. 269; AMSZ, Zespół Depesz (dalej: ZD), t. 53, w. 4, szyfr. nr 1938, W. Wyszyński do Z. Modzelewskiego, Rzym, 8 IV 1946: „W rozmowie poruszono sprawę demobilizacji 2 Korpusu Polskiego Wł. Andersa. Włosi chcą bezwzględnie, aby nie tylko oni, którzy powracają do Polski, ale i inni, opuścili Włochy", b.pag.

${ }^{46}$ Wydawało się to tym bardziej prawdopodobne, że Tito po wizycie w Polsce udał się z wizytą do Czechosłowacji. AMSZ, z. 6, t. 1246, w. 17, amb. J. K. Wende do min. W. Rzymowskiego, Belgrad, 18 II 1946, b.pag.

${ }^{47}$ Cyt za: Z. Rutyna, op. cit., s. 216-217. Według doniesień jugosłowiańskiego MSZ wojska gen. Andersa przegrupowały się i zostały rozlokowane na linii Wenecja-Treviso-Udine.

${ }^{48}$ D. De Castro, op. cit., s. 418-424. Według De Castra Jugosłowianie rozmieścili przy granicy ze strefą A siedem dywizji i 200 wozów opancerzonych. Dysponowali tez znacznymi posiłkami radzieckimi. 
jugosłowiańskim, owocem czego mieli być zabici i ranni ${ }^{49}$. Mimo wycofania jednostek polskich z tego obszaru kampania, eksponująca udział armii Andersa w działaniach określanych jako „akcje prowokacyjne”, przyczyniła się paradoksalnie do pogorszenia atmosfery również między rządem warszawskim a Belgradem, gdyż jak pisał ambasador Wende, „niestety część oburzenia spadła na Polskę w ogóle" 50 .

Zgrupowanie sił po obu stronach stref okupacyjnych w okresie od wiosny do jesieni 1946 r. spowodowało eskalację napięcia, prowadząc do polaryzacji stanowisk mocarstw i ich sojuszników oraz próby konsolidacji sił po obu stronach. Wyrazem dążenia do zwierania szeregów po stronie aliantów oraz przejawem zimnowojennej retoryki było słynne przemówienie W. Churchilla w Fulton (5 III 1946), zawierające apel o ścisłe współdziałanie Wielkiej Brytanii i USA w celu postawienia tamy ekspansji komunizmu, nawiązujące do aktualnej sytuacji na spornym obszarze. („Od Szczecina nad Bałtykiem do Triestu nad Adriatykiem opuściła się żelazna kurtyna w poprzek kontynentu"). Do kumulacji napięcia przyczyniła się również konfrontacyjna postawa ZSRR wspierającego komunistyczną partyzantkę w Grecji, roszczenia terytorialne wobec Turcji, ingerencja w wewnętrzne sprawy Iranu oraz skomplikowana gra przeciw Anglosasom w Chinach.

Zdeterminowana postawa w sporze o Triest, jaką zaprezentował Tito, najwyraźniej wskazywała, iż zmierzał on do postawienia Stalina wobec faktów dokonanych. Nie mogacc pozwolić sobie na rezygnację ze wsparcia ZSRR, dążył do ugruntowania wśród swych potencjalnych sojuszników przekonania, iż przegrupowania brytyjskich sił wojskowych stanowią przygotowanie do zajęcia strefy jugosłowiańskiej (B). W tym też kontekście postrzegał udział żołnierzy 2 Korpusu w incydentach na granicy jugosłowiańsko-włoskiej ${ }^{51}$.

Zaostrzenie sytuacji międzynarodowej oraz zakwestionowanie przez W. Churchilla (5 III 1946) polskiej granicy zachodniej sprawiło, iż Warszawa nie mogła dłużej odkładać wizyty Tity. Jej efektem (odbyła się w dniach 14-20 III 1946) było podpisanie (18 III 1946) Układu o przyjaźni i pomocy wzajemnej między Rzeczapospolitą Polska i Federacyjna Ludowa Republika Jugosławii ${ }^{52}$. Na konferencji prasowej w stolicy Polski Tito skrytykował nie tylko przemówienie W. Churchilla w kontekście granicy na

${ }^{49}$ Z. Rutyna, op. cit., s. 216.

${ }^{50}$ AMSZ, z. 6, t. 1246, w. 17, J. K. Wende do min. W. Rzymowskiego, Belgrad, 18 II 1946, b.pag.

${ }^{51}$ AMSZ, z. 6, t. 248, w. 17, J. K. Wende do W. Rzymowskiego, Belgrad, 7 III 1946, b.pag.

${ }^{52}$ Polska $w$ stosunkach międzynarodowych 1945-1989. Wybór dokumentów, oprac. J. Zając, Warszawa 2005, s. 56-57. O zawartym w 1945 r. polsko-jugosłowiańskim układzie 
Odrze i Nysie, ale też udzielił poparcia rozwiązaniom przyjętym w Poczdamie w sprawie polskich granic, obligując władze w Warszawie do wzajemności w materii postulatów terytorialnych Jugosławii względem Włoch. Pełna aprobata dla żądań Jugosławii znalazła odzwierciedlenie w publikacji dziennika Polskiej Partii Robotniczej „Głos Ludu”"53. Wizyta Tity w Warszawie, a następnie w Pradze miała w przekonaniu dobrze poinformowanych Włochów skłonić obydwa kraje do porzucenia neutralnej postawy wobec kwestii triesteńskiej i stać się okazją dla zamanifestowania wspólnego frontu krajów słowiańskich wobec Zachodu. Według włoskiego chargé d'affaires Carla Soardiego istotnym motywem mogło być również przyszłe zaangażowanie się Belgradu w rozwiązanie terytorialnego sporu polsko-czechosłowackiego ${ }^{54}$.W sprawie ostatecznej postawy polskich władz wobec wschodniej granicy włoskiej akredytowani w Warszawie dyplomaci znad Tybru przedstawiali zaniepokojonej rozwojem wydarzeń centrali sprzeczne opinie. Przeważał jednak optymistyczny pogląd, iż mimo nacisków Jugosłowianom nie udało się uzyskać od strony polskiej wiążących zobowiązań w kwestii triesteńskiej i skłonić ją do porzucenia neutralnej postawy w tej materii ${ }^{55}$. Tym większym zaskoczeniem dla ambasady włoskiej oraz Palazzo Chigi było oświadczenie szefa departamentu prasowego MSZ gen. Wiktora Grosza, a następnie wiceministra Z. Modzelewskiego, złożone na konferencji prasowej po wizycie Tity, że „polski punkt widzenia od końca września [1945 - M.P.] zasadza się na poparciu aneksji Triestu przez Jugosławię przy zachowaniu jego autonomii" ${ }^{56}$. Zaskakujące wieści dochodzące z Warszawy sprawiły, że polsko-jugosłowiański układ stał się przedmiotem indagacji ze strony gremiów kierowniczych włoskiego MSZ, skierowanych wobec urzędni-

gospodarczym i jego konsekwencjach politycznych Włosi pisali już w grudniu 1945 r. Zob. ASMAE, Polonia 1946-1950, 3 busta, A. Jaruso do MSZ, tel., nr 01927, Warszawa, 19 XII 1945.

${ }^{53} \mathrm{~W}$ artykule pisano, że „kraj ten bezspornie jest krajem słowiańskim. Triest jak i całe zaplecze nosi charakter czysto słowiański" Triest i Słoweńskie Pomorze. Słowiański charakter spornego terytorium, „Głos Ludu”, 17 III 1946; zob. J. Zając, R. Zięba, Polska w stosunkach międzynarodowych 1945-1989, Toruń 2004, s. 98-99.

${ }^{54}$ C. Soardi do A. De Gasperiego, Rzym, 19 III 1946, DDI, serie 10, vol. 3, dok. 273.

${ }^{55}$ C. Soardi twierdził jeszcze 16 marca, że Polacy porzucili już życzliwe stanowisko wobec Włoch w tej sprawie. Następnie 22 marca donosił w swej depeszy do Rzymu, że Modzelewski w rozmowie z nim zbagatelizował doniesienia „Głosu Ludu” z 17 marca dotyczące wsparcia przez Polskę dezyderatów Jugosławii. Unikanie jakichkolwiek publicznych deklaracji ze strony polskiej na temat Triestu podczas wizyty Tity w Warszawie C. Soardi interpretował na rzecz tezy o zachowaniu neutralności Polski w kwestii Triestu. C. Soardi do A. De Gasperiego, Rzym, 19 III 1946, DDI, serie 10, vol. 3, dok. 273.

${ }^{56}$ C. Soardi do A. De Gasperiego, Rzym, 22 III 1946, DDI, serie 10, vol. 3, dok. 284. 
ków polskiej ambasady w Rzymie, którzy, zgodnie z instrukcjami, najwyraźniej starali się zminimalizować obawy Rzymu ${ }^{57}$.

Oświadczenie W. Grosza z dnia 22 marca stało się głównym tematem rozmowy ambasadora Reale z wiceministrem spraw zagranicznych Z. Modzelewskim w połowie kwietnia $1946 \mathrm{r}$. Ten ostatni, bez ogródek, potwierdził w jej trakcie, że punkt widzenia zaprezentowany przez wspomnianego urzędnika MSZ został przyjęty już wcześniej, w polskim memorandum z 29 września. Z. Modzelewski dodał, wprawiając włoskiego dyplomatę w osłupienie, że... strona Polska prezentowała właśnie takie stanowisko „niezmiennie przez cały ten okres”. Nawiązując do spotkania z ministrem Rzymowskim w Pradze w końcu lutego 1946 r., włoski dyplomata powoływał się w tej samej rozmowie na zapewnienia swego rozmówcy, że polskie stanowisko przyjęte w tym dokumencie sprowadza się do zaakceptowania przez Polskę zasady etnicznej, przyznającej Jugosławii tylko te tereny, gdzie przeważała ludność słowiańska. Gwarantowała ona Włochom zachowanie obszarów, na których większość stanowili Włosi. Podjęta przez Z. Modzelewskiego próba przedstawienia ostatecznej linii polskiej dyplomacji w tej sprawie wywołała szczególną irytację E. Realego, zyskując miano „grubiańskiej” („grossolano”) i „odrobinę śmiesznej” („un tantinello ridicolo”). Nie na wiele zdały się pokrętne wyjaśnienia ministra o nieporozumieniu czy też wyrażone przekonanie, iż przyłączenie Triestu do Włoch oznaczałoby podupadnięcie portu i nędzę mieszkańców. Podobnie jak nie miała znaczenia argumentacja E. Realego, iż wydarcie Włochom zdecydowanie włoskiego Triestu wywoła nastroje nacjonalistyczne i faszystowskie, wreszcie antykomunistyczne, które mogą zagrozić słabej i jeszcze nieugruntowanej demokracji. Na koniec rozmowy Modzelewski zapewnił swego rozmówcę, iż mimo nacisków Tity Warszawa odrzuciła w podpisanym w marcu układzie jugosłowiańsko-polskim sformułowania o bezpośrednio antywłoskim charakterze, co nie do końca odpowiadało prawdzie. Artykuł trzeci Układu o przyjaźni i pomocy wzajemnej między Rzeczpospolitą Polską i Federacyjną Ludową Republika Jugosławii nie wymieniał co prawda Włoch explicité, ale mówił wyraźnie o „natychmiastowej wojskowej oraz innej pomocy i poparciu wszelkimi środkami” w razie gdyby jedna ze stron została „,w wyniku agresji wciągnięta w działanie wojenne przeciwko Niemcom bądź przeciwko państwu, które było z Niemcami sprzymierzone w ubiegłej wojnie". Trudno z powodu braku bezpośrednich dokumentów rozstrzygnąć, co wpłynęło na

${ }^{57}$ AMSZ, ZD, t. 53, w. 4, szyfr. nr 1938, W. Wyszyński do Z. Modzelewskiego, Rzym, 8 IV 1946: „rozmawiałem dziś [5 kwietnia - M.P.] z R. Prunasem [sekretarzem gen. włoskiego MSZ - M.P.] o układzie polsko-jugosłowiańskim, kierując się instrukcjami. Podkreślił, iż przywiązuje wagę do stanowiska rządu polskiego i są bardzo wdzięczni za nie" [podkreśl.-M.P.],b.pag. 
zmianę ostrożnego stanowiska Warszawy i zaangażowanie się po stronie Belgradu. Późniejszy przebieg wydarzeń zdaje się przemawiać na rzecz tezy, iż dokonała się ona podczas wizyty polskiej delegacji w ZSRR w maju 1946 r., a nie w marcu tego roku ${ }^{58}$. To właśnie w trakcie pobytu w Moskwie delegacji polskiej i jugosłowiańskiej, obok decyzji dotyczących międzynarodowego ruchu komunistycznego i stosunków między ZSRR i Jugosławią, podjęto wiążące ustalenia dotyczące stanowiska krajów satelickich wobec najważniejszych problemów, które miały być omawiane na konferencji w Paryżu ${ }^{59}$. Decyzje, jakie zapadły podczas rozmów na Kremlu, musiały doprowadzić do zmiany strategii polskiego MSZ, przyczyniając się do porzucenia koncyliacyjnej postawy wobec Rzymu.

Kwestionowanie przez mocarstwa zachodnie granicy na Odrze i Nysie Łużyckiej, perspektywa umiędzynarodowienia sporu dotyczącego przebiegu granicy polsko-czechosłowackiej na Zaolziu, przy wyraźnym unikaniu przez Kreml zaangażowania się w konflikt między obydwu krajami, sprawiły, iż rząd polski znalazł się na wiosnę 1946 r. w wyjątkowo niedogodnej sytuacji $^{60}$.

${ }^{58}$ E. Reale do A. De Gasperiego, Warszawa, 15 IV 1946, DDI, serie 10, vol. 3, dok. 357. Układ o przyjaźni i pomocy wzajemnej między Rzeczapospolitą Polska i Federacyjna Ludowa Republika Jugosławii, Warszawa, 18 III 1946 r., w: Polska w stosunkach międzynarodowych, s. 56-57. Wskazywanie Jugosłowianom przez A. Ławriszczewa (szefa sektora bałkańskiego w radzieckim MSZ) - w przeddzień rozmów Stalin-Tito (27 V 1946) - niniejszego passusu polsko-jugosłowiańskiego układu jako wzoru dla przyszłego układu jugosłowiańsko-albańskiego w kwestii wykorzystania go przeciwko ewentualnej agresji włoskiej (bez wymieniania explicité Włoch) może wskazywać na urzędników radzieckich jako autorów lub współautorów układu z 18 marca 1946 r. Takiego passusu brak było w układzie jugosłowiańsko-czechosłowackim z 9 maja 1946 r. Zob. L. Gibianskii, op. cit., przyp. 13 i 33, s. 125, 129.

59 O wizycie delegacji jugosłowiańskiej w Moskwie i rozmowach jugosłowiańsko-radzieckich 27-28 maja 1946 r. - zob. L. Gibianskii, op. cit., s. 115-126. Zob. Soviet and Yougoslav Records of the Tito-Stalin Conversation of 27-28 May 1946, w: L. Gibianskii, op. cit., s. 119. 27 maja Stalin w rozmowie z Titą naciskał na zawarcie aliansu jugosłowiańsko-albańskiego oraz jugosłowiańsko-bułgarskiego. Rozmowa dotyczyła też statusu Triestu (model analogiczny do przedwojennej Kłajpedy lub Gdańska). Mołotow był zwolennikiem przyjęcia modelu Kłajpedy. O pobycie delegacji jugosłowiańskiej w ZSRR 27 V-10 VI 1946 zob: Z. Rutyna, op. cit., s. 228-230; H. Bartoszewicz, op. cit., s. 243-244.

${ }^{60} 24$ kwietnia 1946 r. Czechosłowacja złożyła w Pradze na ręce ambasadorów czterech mocarstw skargę na polskie postępowanie w sprawie Śląska Cieszyńskiego, co spotkało się z negatywnym przyjęciem ze strony Polski, która wystąpiła z zarzutem wobec Czechów o „brak solidarności słowiańskiej”. Dyr. Dep. Polit.jugosłowiańskiego MSZ, płk Brilej, w rozmowie z przedstawicielami polskiej ambasady w Belgradzie potępił ten gest Czechów, zob. AMSZ, z. 6, t. 1246, w. 17, notatka Z. Stena-Stoberskiego z rozmowy z płk. Brilejem, Belgrad, 1 V 1946, b.pag. Według Stalina był to manewr związany z mającymi się odbyć 26 maja 1946 r. wyborami parlamentarnymi w Czechosłowacji.Zob. L. Gibianskii, op. cit., przyp. 51, s. 126. ZSRR podjął próbę mediacji dopiero w lipcu 1946 r. Por. W. Materski, Dyplomacja Polski „lubelskiej”, s. 178. 
Trudno powiedzieć, czy dyplomacja polska liczyła rzeczywiście na mediację Tity w tym sporze, nie mogła jednak pominąć nadarzającej się okazji podjęcia tego problemu. Propozycja dyskusji w oparciu o inicjatywę Tity na temat zatargu, z jaką wystąpił premier E. Osóbka-Morawski w trakcie bankietu wydanego (7 VI 1946) przez W. Mołotowa na cześć jugosłowiańskiego przywódcy, zakończyła się niepowodzeniem. Brak reakcji zarówno ze strony posła czechosłowackiego, jak i gospodarza spotkania wyraźnie świadczy o słabej pozycji przetargowej Warszawy oraz niechęci Kremla do wzmocnienia pozycji Tity wśród wschodnich sojuszników ${ }^{61}$. W okresie późniejszym Jugosłowianie ograniczali się,jak wynika z polskich dokumentów, do ,jak najdalej idącej neutralności” i skierowanych do obydwu stron życzeń ,jak najszybszego porozumienia"62.

Tymczasem E. Reale, zarzucając Polakom, iż, jak to formułował, „w owej sprawie Triestu zachowali się raczej źle” (kładł przy tym nacisk na „niedopuszczalny sposób", w jaki sposób poinformowano Włochów o zmianie stanowiska), zdawał się wykazywać pewne zrozumienie dla ich położenia. Podkreślał w swych raportach, że „ważną przyczyną (obok solidarności słowiańskiej), która popycha Polskę w kierunku ścisłej współpracy z Jugosławią, jest wspólna obrona przed niebezpieczeństwem niemieckim”. Postawa Warszawy mogła być tym łatwiej przełknięta, iż wiceminister Z. Modzelewski potwierdził, że w razie ewentualnej prowokacji jugosłowiańskiej w sprawie Triestu Polska nie udzieli pomocy wojskowej Jugosławii. Obiecywał też poparcie dla włoskich roszczeń wobec Austrii na obszarze Górnej Adygi $^{63}$. Doniesienia E. Realego spotkały się jednak ze sceptycznym przyjęciem centrali. W swym telegramie premier, a zarazem minister spraw zagranicznych A. De Gasperi wskazywał swemu ambasadorowi na stanowisko polskie zawarte w oficjalnym memorandum z 5 października $1945 \mathrm{r}$. Przypominał, że pozostawało ono wszak w sprzeczności z zawartymi w kolejnych raportach opiniami ambasadora o neutralności rządu polskiego w niniejszej kwestii. A. De Gasperi, poruszając problem tzw. „solidarności

${ }^{61}$ W. Materski, Dyplomacja Polski „lubelskiej”, s. 196-197; L. Gibianskii, op. cit, s. 126. Według Leonida Gibianskiego Tito przed spotkaniem ze Stalinem (27 V 1946) zasięgnął opinii Moskwy w sprawie polsko-czechosłowacko sporu o Śląsk Cieszyński. Poinformował też Rosjan, że polski ambasador w Belgradzie prosił go o interwencję na rzecz Polski u Czechów. O naleganiu amb. J.K. Wendego na Titę, aby ten podjął się pośrednictwa w sporze polsko-czechosłowackim, zob. AMSZ, z. 6, t. 1246, w. 6, Ambasada RP w Belgradzie, Z. Sten-Stoberski do MSZ w Warszawie, Belgrad, 2 IV 1946, b.pag.; AMSZ, z. 6, t. 1246, w. 6, J.K. Wende do MSZ, Belgrad, 10 V 1946, b.pag.

${ }^{62}$ AMSZ, z. 6, t. 1246, w. 17, J. K. Wende do J. Olszewskiego, Belgrad, 7 VIII 1946, b.pag.

${ }^{63}$ ASMAE, Polonia 1946-1950, 3 busta, nr 11345, E. Reale do A. De Gasperiego, Warszawa, 23 IV 1946, b.pag., por. E. Reale do A. De Gasperiego, Warszawa, 23 IV 1946, w: E. Reale, op. cit., s. 193-198. 
słowiańskiej” („solidarietà slave”), na którą powoływało się kierownictwa polskiego MSZ, zdobył się na sarkazm, sprowadzający się do konstatacji, iż „potwierdziłaby się ona lepiej, gdyby podjęto próbę złagodzenia, a nie podżegania do skrajnie niedorzecznej postawy jednej ze stron" ${ }^{64}$.

Odnotowując zmianę stanowiska polskiej dyplomacji w okresie poprzedzającym konferencję w Paryżu w kontekście raportów płynących z Warszawy i Moskwy, nad Tybrem zadawano sobie pytanie, czy chodzi tu o samodzielną ewolucję rządu polskiego, która się dokonała pod wpływem czynników zewnętrznych, czy też o zmianę poglądów pod wpływem „rad” płynących z Moskwy. Odpowiedź na pytanie, kto jest odpowiedzialny za zmianę postawy polskich władz: Moskwa czy Tito, miała dla Rzymu w kontekście zbliżającej się konferencji istotne znaczenie. W Palazzo Chigi głowiono się, czy Tito zdołał przeciągnąć na swą stronę Kreml, czy też działał według wskazówek Moskwy. Wydaje się, że włoski MSZ pokładał nadzieje przede wszystkim w nieustępliwym stanowisku Anglosasów wobec roszczeń Belgradu. Skłaniał się do poglądu, iż - mając wybór między Włochami a Jugosławią - Stalin poprze w sporze o Triest Titę. Sądzono, iż utrata Triestu przez Jugosławię mogłaby spowodować upadek tego polityka, a w konsekwencji zachwiać wpływami Kremla w tej części Europy. „Zagrożenie dla demokracji”, jakie stwarzałaby dla Jugosławii utrata Triestu, skłaniało Stalina, według kierownictwa włoskiego MSZ, do wsparcia Tity ${ }^{65}$. Pragmatyczna postawa przywódcy ZSRR, przejawiająca się w odrzuceniu żądań włoskich komunistów przyjęcia „,bardziej życzliwej postawy wobec kwestii Triestu", wynikała z obawy przed poważniejszymi konsekwencjami utraty tego miasta i jego obszaru, które mogły prowadzić do zachwiania radzieckich wpływów w Europie południowo-wschodniej ${ }^{66}$. To właśnie postawa ZSRR, a nie Polski na przyszłej konferencji była przedmiotem spekulacji nad Tybrem. Włosi nie kryli jednak przed swymi polskimi rozmówcami, że ich delegacja na konferencję paryską nie zaakceptuje „niesprawiedliwych warunków traktatu” noszących „znamiona zemsty" oraz odrzuci zaproponowany przez RMSZ podział spornego terytorium. Ambasador Reale przekonywał dyrektora departamentu politycznego polskiego MSZ Józefa Olszewskiego, że premier A. De Gasperi ma $\mathrm{w}$ tej sprawie poparcie całego społeczeństwa oraz establishmentu poli-

64 „la solidarietà slave si affermerebbe, io credo, tanto meglio se tentasse di smussare; invece che eccitare gli irragionevoli estrmismi di una delle sue parte", A. De Gasperi do E. Realego, Rzym, 5 V 1946, DDI, serie 10, vol. 3, dok. 413.

${ }^{65}$ ASMAE, Polonia 1946-1950, 3 busta, nr 843, A. De Gasperi do amb. w Londynie, Waszyngtonie, Warszawie, Rzym, 9 VII 1946, b.pag.

${ }^{66}$ Cyt za: E. Aga-Rossi, V.Zaslavsky, op. cit., s.143-144; S. Pons, op. cit., s. 13. 
tycznego, w tym również komunistów ${ }^{67}$. Stanowiło to wyraźny sygnał kierowany nie tylko pod adresem Warszawy.

Stanowisko Kremla nabierało szczególnego znaczenia w obliczu rozbieżności stanowisk ministrów spraw zagranicznych czterech mocarstw obradujących w Paryżu i odrzucenia przez Włochów i Jugosłowian (17 VII 1946) kompromisowego rozwiązania dotyczącego utworzenia Wolnego Terytorium Triestu (WTT) i podziału Krainy Julijskiej, zaproponowanego przez Francję ${ }^{68}$.

Na rozpoczętej 29 lipca konferencji paryskiej dwudziestu jeden państw Włosi i Jugosłowianie protestowali przeciwko powyższemu rozwiązaniu, domagając się ponownego rozpatrzenia tej kwesti6 ${ }^{69}$. W lipcu 1946 r. kierownictwo polskiego MSZ, zdając sobie sprawę, iż nie da się już kontynuować taktyki odwlekania i pustych obietnic, postanowiło przedstawić Włochom swoje oficjalne stanowisko. Zdawano sobie bowiem sprawę, że w trakcie konferencji nie można będzie uniknąć zajęcia określonej postawy w kwestii granicy włosko-jugosłowiańskiej. Podczas rozmowy z E. Realem minister Z. Modzelewski oświadczył bez ogródek, iż w czasie konferencji paryskiej „ze względu na niebezpieczeństwo niemieckie delegacja polska będzie musiała udzielać stanowczego poparcia propozycjom wysuwanym przez Związek Sowiecki”. Nic więc dziwnego, iż E. Reale w swym kolejnym raporcie z Warszawy donosił, że „należy się wyzbyć wszelkich iluzji, iż polska delegacja mogłaby powziąć jakąś decyzję sprzeczną czy nawet nieco odmienną [podkreśl. - M.P.] od stanowiska, jakie zajmą Sowiety"70. Takich iluzji zresztą w Wiecznym Mieście nie żywiono. Mimo iż delegacja polska na konferencję w Paryżu otrzymała z centrali instrukcję o konieczności zajęcia względem Austrii i Włoch „łagodnego stanowiska" ${ }^{\text {, to }}$

${ }^{67}$ ASMAE, Polonia 1946-1950, 3 busta, nr 938, E. Reale do A. De Gasperiego, Warszawa, 12 VII 1946, b.pag.

${ }^{68}$ D. De Castro, op. cit., s. 463-466; K. Szczepanik, J. Wilamowski, op. cit., s. 110-111; R. Zięba, op. cit., s. 87-88. Tzw. linia francuska zaproponowana przez premiera i min. spraw zagr. Francji Georges'a Bidaulta zakładała utworzenie z okolic Triestu oraz z części Istrii Wolnego Terytorium, którego suwerenność miała być zagwarantowana przez Radę Bezpieczeństwa ONZ. Jego statut miał być zostać ułożony przez komisję mieszaną czterech mocarstw, przy współudziale Włoch i Jugosławii, i przedłożony do akceptacji na konferencji pokojowej w Paryżu. Zob. D. De Castro, op. cit., s. 440. Według Rosjan linia francuska była zręcznym posunięciem, inspirowanym przez Wielką Brytanię i USA. Amerykanie odrzucili radzieckie propozycje organizacji WTT na zasadzie przedwojennej Kłajpedy. Zob. V.O. Pechatnov, op. cit., s. 17, 18.

${ }^{69}$ Zob. R. Zięba, op. cit., s. 83.

${ }^{70}$ E. Reale do A. De Gasperiego, Warszawa, 30 VII 1946, w: E. Reale, op. cit., s. $266-267$.

${ }^{71}$ J. Winiewicz, Co pamiętam z długiej drogi życia, Poznań 1985, s. 367. Stosunek do 
zgodnie z powyższą enuncjacją nie mogło ono odbiegać od postawy Kremla. Polityka nieangażowania się w spory mocarstw oraz akceptacja podjętych przez RMSZ decyzji w sprawie umiędzynarodowienia miasta i portu w Trieście, lansowana przez kierownictwo polskiego MSZ, nie miała szansy na realizację ${ }^{72}$. Na konferencji paryskiej delegacja polska została zmuszona do zajęcia stanowiska w sprawie modyfikacji przyjętej przez RMSZ (3 lipca) „linii francuskiej” i poparcia żądań Belgradu, które uprzednio oceniała jako zbyt roszczeniowe ${ }^{73}$.

Sprowadzało się ono do wspierania poprawek dotyczących wspomnianej linii, zgłoszonych przez delegację białoruską. Zakładały one jej modyfikację na korzyść Jugosławii (przyznając jej Gorycję) oraz zmierzały wyraźnie do ograniczenia obszaru WTT (Triest i jego przedmieścia). Poprawki miały na celu zapewnienie łączności WTT z Jugosławią poprzez przekazanie jej obszaru zachodniej Istrii. W tym duchu przemawiał Józef Winiewicz i pozostali członkowie polskiej delegacji, akcentując konieczność likwidacji „korytarza” łączącego Triest z Włochami poprzez przekazanie spornego obszaru Jugosławii ${ }^{74}$.Sprawy dotyczące funkcjonowania WTT stały się tematem kolejnych polskich wystąpień, zawierających ostrzeżenia przed powtórzeniem rozwiązań prawnych zastosowanych w przedwojennym Gdań$\mathrm{sku}^{75}$. Można domniemywać, iż na „wzmocnienie” zaangażowania strony polskiej na rzecz Jugosławii oraz retorykę delegatów Warszawy, odwołującą się do negatywnych doświadczeń II RP z Gdańskiem i Prusami Wschodnimi, wpływ miało głośne przemówienie amerykańskiego sekretarza stanu Jamesa Byrnesa (6 września), kwestionujące trwałość przebiegu granicy na

Włoch miał być równocześnie „inny” niż wobec Bułgarii, Rumunii i Węgier (wobec tych ostatnich postulowano stosunek - „życzliwy i łagodny”).

${ }^{72}$ E. Reale do A. De Gasperiego, Warszawa, 30 VII 1946, w: E. Reale, op. cit., s. 261. Modzelewski w rozmowie z Realem wyraził niechęć względem wznowienia dyskusji nad sprawą Triestu podczas konferencji paryskiej, uważając decyzję RMSZ czterech mocarstw z 3 lipca 1946 r. za kompromis. Zob. też: ASMAE, Polonia 1946-1950, 4 busta, nr 123, C. Soardi do A. De Gasperiego, Warszawa, 10 VIII 1946, b.pag.

${ }^{73}$ Mówił o tym w rozmowie z E. Realem min. Z. Modzelewski (30 VII 1946). Zob. E. Reale, op. cit., s. 261. Kompromisowy projekt francuski przewidywał zdemilitaryzowanie i zneutralizowanie WTT. Kompetencje gubernatora zostały ograniczone (w porównaniu do projektów brytyjskiego i amerykańskiego) na rzecz zgromadzenia ustawodawczego.

${ }^{74}$ R. Zięba, op. cit., s. 83-90.

${ }^{75}$ Wstąpienia polskiej delegacji, m.in. J. Winiewicza (6 września, 14 września, 3 X 1946), Stefana Wierbłowskiego (11 IX 1946) oraz W. Rzymowskiego (8 X 1946), odwoływały się do efektownych porównań Triestu i Włoch do przedwojennego Gdańska i Prus Wschodnich i dotyczyły roli, jaką w przyszłości mógł odegrać zamieszkany w większości przez Włochów Triest „w przypadku stania się ośrodkiem włoskiego nacjonalizmu”, oraz znaczenia korytarza łączącego go z Włochami. Szerzej na ten temat: zob. R. Zięba, op. cit., s. 89-90, oraz Z. Rutyna, op. cit., s. 266 n. 
Odrze i Nysie Łużyckiej. Spotęgowało ono poczucie zagrożenia polskich władz, wzmacniając idee nawiązujące do tzw. solidarności słowiańskiej.

Wystąpienia strony polskiej zmierzające do ścisłego związania WTT z Jugosławią nie wpłynęły jednak na ostateczną decyzję komisji polityczno-terytorialnej do spraw Włoch. Przyjęła ona „linię francuską”, nie uwzględniając roszczeń Jugosławii w sprawie przyznania jej Gorycji i Monfalcone oraz ograniczenia obszaru WTT ${ }^{76}$.

Kolejnym problemem, w który zaangażowała się polska delegacja na forum międzynarodowym, była kwestia statutu WTT. Zagadnienie to, ze względu na ważne znaczenie strategiczne portu oraz jego przyszłość, stało się przedmiotem rozgrywki między przedstawicielami ZSRR, jego adherentami a mocarstwami zachodnimi. Te ostatnie, obawiając się podjęcia przez Titę działań militarnych zmierzających do zajęcia Triestu, były zwolennikami utworzeniem z WTT niezależnego organizmu pod nadzorem Rady Bezpieczeństwa ONZ i wyposażenia gubernatora (mianowanego przez Radę Bezpieczeństwa) w szeroki zakres uprawnień kosztem lokalnych władz ustawodawczych i wykonawczych ${ }^{77}$. Delegacja polska śladem delegacji jugosłowiańskiej i radzieckiej zwalczała koncepcję wyposażenia urzędu gubernatora w szerokie uprawnienia, wypowiadając się za rozszerzeniem roli władz lokalnych, wzmocnieniem związków łączących miasto z Jugosławią. Jej postulaty miały na celu zerwanie więzi tego organizmu $\mathrm{z}$ Włochami, co miało prowadzić do wchłonięcia go przez Jugosławię ${ }^{78}$.

Polacy jednak nie wierzyli w możliwość uzyskania aprobaty Anglosasów dla tego rozwiązania, podkreślając „,przynajmniej czasowe przegranie Triestu" przez Titę. Byli też (tak jak i ZSRR) sceptyczni względem możliwości bezpośredniego porozumienia się Włochów i Jugosłowian z pominięciem aliantów. Uważali (wzorem ZSRR), iż propozycja Tity, przedłożona P. Togliattiemu na jesieni 1946 r., sprowadzająca się do zamiany Triestu na Gorycję (która nie należała do strefy jugosłowiańskiej), była jedynie krokiem taktycznym, mającym na celu, poza efektami propagandowymi, wyprowadzenie Anglosasów ze strefy B i utrudnienie aliantom zachodnim roztoczenia „opieki” nad spornym terytorium ${ }^{79}$.

${ }^{76}$ R. Zięba, op. cit., s. 91-92.

${ }^{77}$ K. Szczepanik, J. Wilamowski, op. cit., s. 111.

${ }^{78}$ R. Zięba, op. cit., s. 92-102. Zob. też: AMSZ, z. 6, t. 1266, w. 83, Oświadczenie delegacji polskiej na posiedzeniu Komisji Polityczno-Terytorialnej Włoch złożone w sprawie statutu Triestu, 2 X 1946, b.pag.

${ }^{79}$ AMSZ z. 6, t. 1246, w. 17, Raport ambasady RP w Jugosławii, Belgrad, 10 XI 1946. Według S. Ponsa ZSRR przypisywał rozmowom Tito-Togliatti jedynie znaczenie propagandowe, zob. S. Pons, op. cit., s. 13-14. 
Odrzucenie przez mocarstwa zachodnie postulatów jugosłowiańskich, wspieranych przez „bratnie” delegacje (w tym polską), mimo ostatecznego przyjęcia kompromisowego projektu francuskiego w postaci zaleceń dla RMSZ ${ }^{80}$ oraz podpisania przez Włochy i Jugosławię traktatów pokojowych (10 II 1947) nie oznaczało końca konfliktu, którego dalszy ciąg miał się rozegrać w zaostrzającej się sytuacji międzynarodowej. Brak określonej i konsekwentnej linii politycznej wobec zachodnich partii komunistycznych (w tym WłPK) oraz brak zdecydowanej pomocy i zrozumienia dla ich narodowych aspiracji (jak w wypadku znaczenia Triestu dla legitymizacji WłPK) doprowadziły nie tylko do dezorientacji w gremiach kierowniczych tych partii, ale i do stopniowej utraty ich popularności w społeczeństwie. Przełożyło się to w realiach zachodnich na przegraną w wyborach parlamentarnych i usunięcie komunistów z rządów co we Włoszech dokonało się po wiosennych wyborach 1948 r. - i wiązało się z wejściem na drogę w kierunku rodzącego się bloku zachodniego ${ }^{81}$.

Ogłoszenie doktryny Trumana, odrzucenie przez państwa satelickie ZSRR planu Marschalla oraz utworzenie Kominformu doprowadziły do podziału świata na dwa zwalczające się bloki. Jego konsekwencją był wzrost napięcia nie tylko w stosunkach między mocarstwami, ale i państwami znajdującymi się w orbicie ich wpływów. Postawa polskiej dyplomacji, postrzeganej na zewnątrz przez pryzmat mocarstwowej polityki Kremla, nie mogła mieć większego wpływu na rozwój wydarzeń na scenie międzynarodowej. Dalszej instrumentalizacji uległa również polityka zagraniczna Włoch, które ze względów strategicznych, politycznych i gospodarczych zostały w swych działaniach całkowicie uzależnione od polityki Waszyngtonu. Wszystko to sprawiło, iż wymiana poglądów na temat kwestii triesteńskiej w relacjach polsko-włoskich stała się bezprzedmiotowa. Dyplomacja obydwu krajów pozbawiona została możliwości swobodnego działania i artykułowania swoich własnych interesów. Polityka równych odległości i przyjaźni wobec wielkich mocarstw, której pozory starał się zachować rząd Ivanoe Bonomiego i De Gasperiego, nie miała w warunkach powojennej zapaści ekonomicznej Włoch i ścisłej zależności gospodarczej od USA żadnych szans na urzeczywistnienie. Leaderzy

${ }^{80}$ Z. Rutyna, op. cit., s. 264-274. R. Zięba, op. cit., s. 92-102. 9 października 1946 r. plenum konferencji paryskiej uchwaliło bez zmian francuski projekt WTT.11 grudnia 1946 r. statut WTT został zaakceptowany przez cztery mocarstwa. RMSZ na posiedzeniu czterech mocarstw w Nowym Jorku przyjęła ostatecznie statut WTT, według zaleceń konferencji pokojowej w Paryżu. Został on włączony do traktatu pokojowego jako Aneksy VI-X. 10 lutego 1947 r. Jugosławia podpisała traktat pokojowy z Włochami. Złożyła jednak oświadczenie, że nie rezygnuje z ziem, które według kryteriów etnicznych powinny do niej należeć.

${ }^{81}$ Zob. S. Pons, op. cit., s. 13-21. 
polityczni tego kraju nie kryli zresztą kłopotów, z jakimi borykały się kolejne rządy włoskie, i związanych z tym oczekiwań na pomoc ze strony zagranicy. Wskazywali na ten aspekt w rozmowach z radzieckimi przywódcami, podkreślając, że braki w dziedzinie aprowizacji oraz dostaw surowców (zwłaszcza węgla) uniemożliwiają im prowadzenie bardziej niezależnej i śmiałej polityki zagranicznej ${ }^{82}$. Być może należałoby się zgodzić z wyrażanymi przez niektórych badaczy opiniami, że Włosi musieli porzucić nadzieję na bardziej niezależną politykę, w tym na rozgrywanie „karty rosyjskiej” na swą korzyść, obawiając się, iż Moskwa może rozegrać „problem włoski" ich kosztem, w interesie swych bułgarskich i rumuńskich satelitów ${ }^{83}$. Sytuację Polski i Włoch doskonale oddawała konstatacja ambasadora Włoch w ZSRR, P. Quaroniego, który w połowie 1948 r. stwierdził, iż „realna sytuacja jest taka, że tak jak wszystkie inne kraje europejskie przestaliśmy być krajem niezależnym, i mamy taką swobodę w zbliżeniu się do Rosji jak Polska w zbliżeniu do USA"84.

W przekonaniu włoskiej opinii publicznej jak i elit rządowych uznanie Włoch za „naród pokonany” oraz odmowa przez mocarstwa przyznania im statusu sojusznika aliantów pociągnęło za sobą konsekwencje w postaci ocenianych jako „krzywdzące” i „niesprawiedliwe” warunków pokojowych ${ }^{85}$. Włoska nota protestacyjna, złożona w polskim MSZ zaraz po podpisaniu przez Włochy traktatów paryskich, zapowiadała podjęcie starań o złagodzenie „w praktyce” „szczególnie surowych postanowień”. Miała na celu wysondowanie stosunku polskich władz do zapowiadanych

${ }^{82}$ Podczas rozmowy z W. Mołotowem w Paryżu (14 VIII 1946), sondując najwyraźniej Kreml w kwestii ewentualnych dostaw surowców, A. De Gasperi przedstawił otwarcie stanowisko, że Włosi otrzymali w ramach pomocy UNRRA w „formie dostaw” miliard dolarów. Stwierdził też, że „życie codzienne Włoch zależy od Ameryki”. Zob. R. Morozzo Della Rocca, op. cit., s. 146-153.

${ }^{83}$ Bruno Arcidiacono twierdzi, iż Włosi zrezygnowali z prowadzenia polityki niezależnej od USA już na wiosnę 1945 r. Zob. idem, La politique soviétique en Italie (19431945), „Relations Internationales” 1986 , 45, s. 48-49. W naszym przekonaniu nastąpiło to jednak podczas konferencji paryskiej - M.P.

${ }^{84}$ Tel. P. Quaroniego, do A. Tarchianiego, Moskwa, 2 VI 1948., cyt. za: P. Guillen, Le déclin de la puissance italienne à la fin de la seconde guerre mondiale, „Relations Internationales" 1977, 9, s. 19.

${ }^{85} \mathrm{P}$. Guillen, La réinsertion internationale de l'Italie après la chute de fascisme, „, Relations Internationales” 1982, 31, s. 346. Od początku rząd włoski uważał traktaty pokojowe za „niesprawiedliwe” i „anachroniczne”. Zob. B. Vigezzi, De Gasperi, Sforza, la diplomazia italiana e la percezione della politica di potenza dal trattato di pace al Patto Atlantico (1947-1950), „Storia Contemporanea” 16, 1985, 4, s. 665-666; C. Sforza, Cinque anni a Palazzo Chigi. La politica estera italiana dal 1947 al 1951, Roma 1952, s. 432; E. T. Smith, From Disarmament to Rearmament: The United States and the Revision of the Italian Peace Treaty of 1947, „Diplomatic History” 13, 1989, 3, s. 360. 
w nocie kroków ${ }^{86}$. Mimo ogólnikowych sformułowań o „życzliwości” wobec Włoch kierownictwo polskiego MSZ nie kryło konieczności zaakceptowania przez Rzym ustaleń, które zapadły w Paryżu. W rozmowach z włoskimi dyplomatami wskazywano na zasadność podjętych tam decyzji oraz konieczność rezygnacji z wszelkich pretensji terytorialnych ${ }^{87}$. Zdaniem strony polskiej rezygnacja Rzymu z roszczeń terytorialnych wobec Jugosławii stanowiła gwarancję pokoju w Europie. Minister Z. Modzelewski w rozmowach z przedstawicielami włoskiej ambasady wskazywał na konieczność wyrzeczeń, przywołując przykład Polski, która musiała zrzec się „naszych wschodnich ziem na wschód od Bugu”, Lwowa, oraz przyjąć „ustępliwą linię wobec Czechosłowacji w kwestii Cieszyna". Warszawa zresztą, sugerując Rzymowi przyjęcie analogicznej linii postępowania w kwestii traktatów pokojowych, ,szczególnie niemiło”, jak donosili włoscy dyplomaci, przyjmowała wszelkie wzmianki na temat rewizji umów ${ }^{88}$. Nic więc dziwnego, iż Polska, która była sygnatariuszem traktatów pokojowych, pragnąc utrwalenia status quo, wszczęła wiosną $1947 \mathrm{r}$. ich procedury ratyfikacyjne ${ }^{89}$.

Uregulowanie problemu Triestu nastąpiło dopiero po podpisaniu (1 VIII 1975) Aktu Końcowego Konferencji Bezpieczeństwa i Współpracy w Europie, w zgoła już w odmiennej atmosferze. Jego ukoronowaniem stało się podpisanie w Osimo (10 XI 1975) przez Jugosławię i Włochy stosownych porozumień. $\mathrm{W}$ ich świetle włosko-jugosłowiańska granica miała być ustanowiona na bazie linii rozdzielającej strefę A i B (z niewielkimi przesunię-

${ }^{86}$ AMSZ z. 6, t. 1247, w. 81, Nota rządu włoskiego, 12 II 1947, b.pag.; AMSZ z. 6, t. 1247 , w. 81, notatka z rozmowy min. J. Olszewskiego z C. Soardim w ob. Radcy S. Nahlika, 14 II 1947, b.pag.

${ }^{87}$ ASMAE, Polonia 1946-1950, 9 busta, nr 1127, C. Soardi do C. Sforzy, Warszawa, 19 II 1947, b.pag.

${ }^{88}$ „Noi - ha detto il Ministro (Modzelewski) - abbiamo dato un esempio: credete forse che non sia una spina nel cuore di tutti i Polacchi la rinuncia a Leopoli ed alle nostre Terre ad oriente del Bug? E siamo sulla via di adottare una analoga linea conciliante nei confronti della Cecoslovacchia per la questione di Teschen", C. Soardi do C. Sforzy, Warszawa, 19 III 1947, DDI, serie 10, vol. 5: (2 febbraio-30 maggio 1947), red. E. Di Nolfo, Roma 1997, dok. 225. Zob. też: ASMAE, Polonia 1946-1950, busta 9, nr 1912, C. Soardi do P. Nenniego, Warszawa, 31 IV 1947, b.pag.

8914 maja 1947 r. Rada Ministrów podjęła uchwałę w sprawie ratyfikacji traktatu. Na tej podstawie 27 maja minister Z. Modzelewski przesłał do Sejmu projekt ustawy ratyfikacyjnej. 14 listopada 1947 r. Sejm uchwalił ratyfikację traktatu pokojowego z Włochami, udzielając zgody na jego ratyfikację przez prezydenta. 3 grudnia $1947 \mathrm{r}$. Bolesław Bierut dokonał formalnej ratyfikacji traktatu. 4 lutego 1948 r. amb. Jerzy Putrament złożył dokument ratyfikacyjny we francuskim MSZ. W tym dniu zgodnie $z$ art. 90. traktat pokojowy z Włochami wszedł w życie ze skutkami prawnymi dla Polski.Zob. R. Zięba, op. cit., s. 178-179. Na temat podjętej przez Polskę ratyfikacji zob. też: A. Donini do C. Sforzy, Warszawa, 14 XI 1947, DDI, serie 10, vol. 6: (31 maggio-14 dicembre 1947), red. P. Pastorelli, Roma 1997, dok. 729. 
ciami o charakterze technicznym). Z punktu widzenia prawa międzynarodowego kwestia niniejsza została definitywnie uregulowana w roku 1979, po ratyfikacji układów z Osimo przez parlamenty obu państw ${ }^{90}$.

The Dispute about Trieste in Polish-Italian Relations in 1945-1947

The recognition of Poland as a signatory of the peace treaty signed with the satellite states of the Third Reich was the reason why Warsaw became a member of a political-territorial and economic commission dealing with Italy at the Paris conference (29 July-15 October 1946). Hence, i.a. the efforts made in Rome involving Poland and its support for Italian postulates concerning a priority question, i.e. the administration of Trieste by Italy. Despite promises of backing the Italian proposals, Polish diplomacy, embroiled in the games played by the Kremlin with the great powers, was compelled to withdraw and in the course of preparations for the Paris conference and subsequently in its course it assumed a stand favourable towards Yugoslavia. The dependence of Polish diplomacy on Moscow and the subjugation of Italian policies to Washington meant that Cold War relations between Rome and Warsaw were of secondary importance for both countries.

Translated by Aleksandra Rodzińska-Chojnowska

${ }^{90}$ K. Szczepanik, J. Wilamowski, op. cit., s. 117. 